\title{
The Ex-Ante Evaluation of Hotel Buildings Height in Airport Area: A Case of Hotel in Kaliwungu, Peri-Urban Area of Semarang
}

\author{
Anang Wahyu Sejati ${ }^{1}{ }^{2}$, Sri Rahayu ${ }^{1}$, Bitta Pigawati ${ }^{1}$, Jurike Winarendri ${ }^{3}$ \\ 1. Department of Urban and Regional Planning, Universitas Diponegoro, Semarang, Indonesia \\ 2. Doctoral Program in Architecture and Urbanism, Universitas Diponegoro, Semarang, Indonesia \\ 3. Department of Urban environmental management, Wageningen University, The Netherlands \\ *) Corresponding e-mail: anang@live.undip.ac.id
}

\section{Article info:}

Received: 04-08-2018; Revised: 13-09-2018; Accepted: 14-09-2018

\begin{abstract}
This paper conveys the findings on hotel buildings evaluation in the peri-urban of Semarang based on ex-ante evaluation. Ex-ante is an evaluation model before project activities are implemented to minimize development impacts. Evaluation of altitude was done with three models, namely the ratio of floor area (FAR), Angle of Light Obstruction (ALO), and building height calculation in the airport area applicable in Indonesia. Furthermore, the evaluation of the strategic value of the location with three criteria was the proximity of industrial zone, accessibility, and proximity to tourist destinations. This study successfully answered the question of maximal height rules and the number of stories allowed for hotel buildings in peri-urban Semarang. The result suggests the regulation of building height in Kaliwungu especially for hotel buildings in aviation safety area. Maximum height allowed is $32.5 \mathrm{~m}$ or 8 stories. The existing regulations have not regulated these issues, so collaborative planning should be carried out between the government of Semarang City and Kendal Regency. With collaborative planning, problems in both regions, especially regarding the height of buildings such as hotels can be coordinated.
\end{abstract}

Keywords: Ex-ante evaluation, Hotel, Aviation Safety, Kaliwungu District, Semarang Peri-Urban Area

\section{Introduction}

Hotels and tourism play an important role in the urban economy in the modern era (Ben-David, Teitler-Regev, \& Tillman, 2016). This phenomenon can not be separated from the role of hotels as a facility and container of community activities in the tourism (Assaf, Josiassen, \& Agbola, 2015; Madanoglu \& Ozdemir, 2016; Z. Yang \& Cai, 2016). The hotel services are thriving and providing convenience for tourists especially in digital offerings which greatly affect the number of requests (De Pelsmacker, van Tilburg, \& Holthof, 2018). Furthermore, the success factors of the hotel businesses are the location and marketing, especially the ones in the tourist destinations (Adam \& Amuquandoh, 2013; Lado-Sestayo \& Fernández-Castro, 2018). Therefore, locations are the crucial aspect because it affects accessibility and hotels' revenues.

Today, hotels do not only function as an inn but also function as the center of various tourism supporting activities (Rogerson, 2013; Shoval, McKercher, Ng, \& Birenboim, 2011). The rising number of meetings, incentives, conferences and exhibitions (MICE) is the factor behind the increasing demands for hotels. The hotels start to offer lodging packages with exciting MICE facilities. In international scale, MICE is not only seen as regular activities of urban society, but they are also service industry that has great potential for regional development (Whitford, 2009). The presence of MICE has given a variety of colors to the type of service industry activities that are identical with the provision of services. Economically, MICE is a highly contributing business that absorbs labors and the flow of goods (Hermawan \& Syahbana, 2015).

Interesting problems occur in the hotel businesses especially in land availability. The number of MICE activities is increasing in the city centers such as commercial and administration centers, but the land availability for hotels is limited. Furthermore, the increased land prices in the city centers have brought impact to hotel growth in some countries. Although the land is 
available, the offered prices are so high that some local hotel entrepreneurs prefer locations outside the city centers.

The same problem also occurs in Semarang Metropolitan Region (SMR). As one of national strategic areas of Indonesia, SMR experiences problems in providing land for hospitality businesses in its city centers. The number of demands for hotels increases, but the price of land in the city center is very expensive. Only big investors can survive in this hospitality business. This condition forced hotel entrepreneurs to choose peri-urban areas as the target of their business development. The data reveal that the accommodation business in SMR has increased as many as $9-12 \%$ per year since 2010 (Central Bureau of Statistics, 2017). It shows that the hotel businesses are starting to develop and eventually require land availability SMR areas are potential the hotel growth. The number of built-up areas growing as many as $1.2 \%$ per year (Sejati, Buchori, \& Rudiarto, 2018) provides evidence that SMR continues to develop area particularly in its urban areas. Furthermore, MICE activities that are integrated with activity centers are inseparable from urban and industrial activities (Hermawan \& Syahbana, 2015). Hence, land prices determine the hotel growth in the city centers. With these problems, the local government has provided locations for hotel development in the peri-urban areas.

The government has recommended Kaliwungu as the location for the hotel development. Although located in peri-urban, Kaliwungu is a strategic area because it is situated at the primary access as well as close to the airport and seaport. The area close to the airport is very profitable when viewed from the side of demands. However, like what Wilke et al. (2015) explained that aviation safety is a challenge for airline providers, this location is in the aviation safety path hence affecting the height of hotel buildings. Furthermore, the landscape and the environment of the airport become one of the factors that greatly influence the aviation safety (Wilke et al., 2015). This condition has brought a new problem regarding regulations of building height in the airport area. The hotel should consider the height of the building, so it will not disrupt the aviation safety path. Focusing on this issue, it is necessary to consider the safe height for hotel buildings with scientific approach.

This study differs from previous studies of hotels and building height regulations. Previous studies focused on the access and proximity to tourism attractions (Adam \& Amuquandoh, 2013; Assaf et al., 2015; Y. Yang, Luo, \& Law, 2014; Y. Yang, Wong, \& Wang, 2012). Furthermore, the latest research on building height regulation is about the land regulation (Ding, 2013). Based on the previously mentioned studies, the study on building heights integrated with airport regulations need to be conducted. This study focuses more on the height of hotel building in the airport environment and the strategic value of the future hotel location. Thus, the aims of the study are to estimate the hotel's maximum altitude on the airport flight area and the number of stories to maximize hotel revenues with the ex-ante evaluation model. This model is an evaluation model employed before project activities are implemented to minimize development impacts. Thus, the results of this study can be a useful advice for local governments in regulating the buildings height, especially in peri-urban areas that have proximity to the airport.

\section{Methods}

\subsection{The Area of the Study}

This research took place in Kaliwungu District and the aviation safety area of Ahmad Yani International Airport (AYIA). It is the part of SMR with coordinates of the location of future hotels location is $6^{\circ} 56^{\prime} 46 S$ and $110^{\circ} 15^{\prime} 55^{\prime \prime} \mathrm{E}$. The detail location was illustrated in Figure 1 (Gita, Subiyanto, \& Nugraha, 2014). 


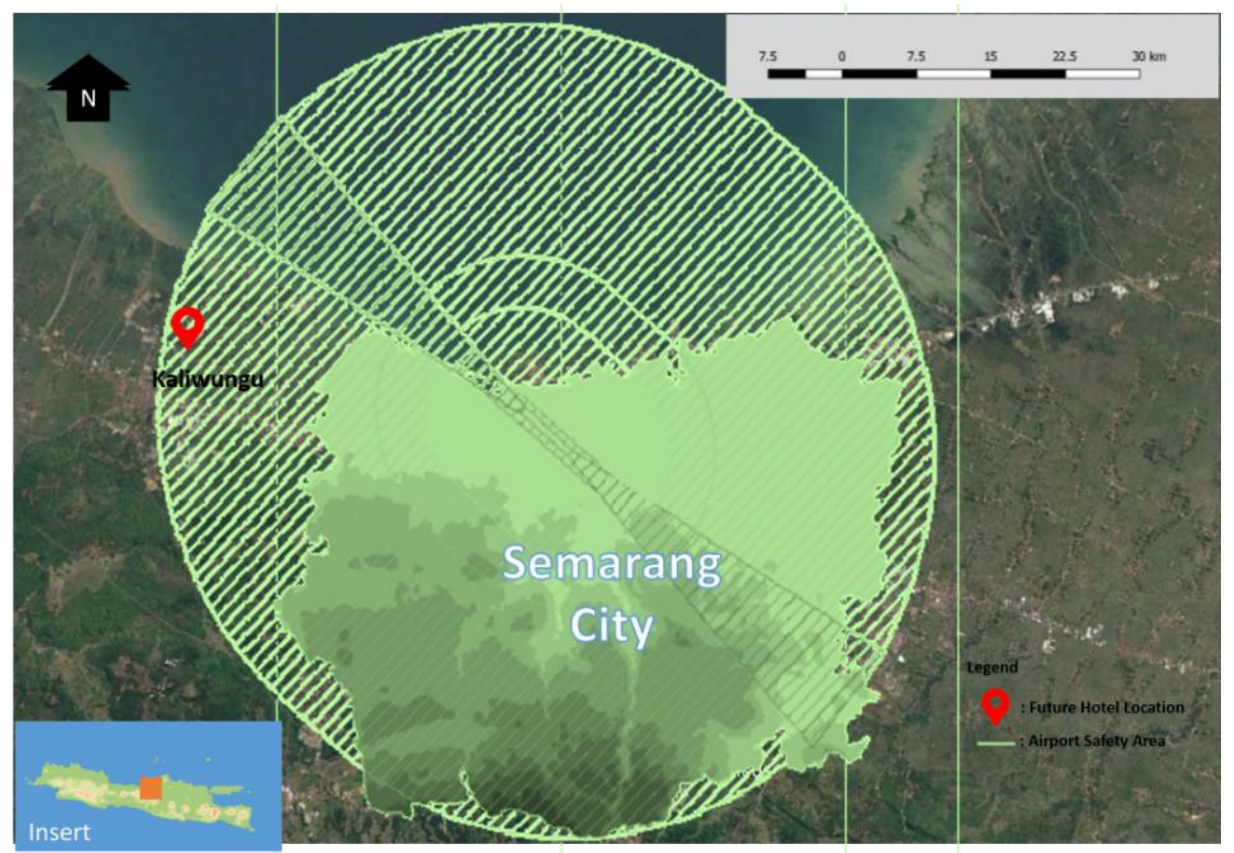

Source: Modified from Gita, Subiyanto, \& Nugraha (2014)

Figure 1.The Study Location in the Safety Area of Ahmad Yani International Airport

\subsection{The components of ex-ante evaluation}

This research used the ex-ante evaluation model, the evaluation process undertaken prior to the project (Doğan, Doğan, \& Yıldız, 2018). Furthermore, the evaluation was conducted to predict the similar cases such as an evaluation of transportation projects or an evaluation of environmental sustainability programs (van Sluisveld et al., 2017; van Wee, 2012). The components assessed in the ex-ante evaluation were hotel altitudes that involve various models. The first model is called Floor Area Ratio (FAR), defined as the ratio between floor spaces in a building (Handy, Boarnet, Ewing, \& Killingsworth, 2002). FAR strongly affects the skyline which is created by surrounding sets of the building. The purpose of determing FAR is related to the rights of every person/building to receive sunlight as energy in the amount equal to the surrounding buildings; with calculations as in Equation (1) and (2).

Floor Area $=$ Building floor Coefficient $(B F C) \times$ Total Area of Hotel Siteplan

Floor Area Ratio $=$ Total Area of Hotel Siteplan $/$ Floor Area

Furthermore, the second model was the Angle of Light Obstruction (ALO) model. Using ALO to estimate altitude was useful in providing natural lighting with the consideration of energy saving (Shirvani, 1985) with calculation models such as Equation (3) and (4);

$$
\begin{aligned}
& h_{\text {tot }}=0,5(F d+S d+B d) \operatorname{tg} \alpha \\
& h_{\max }=h_{\text {tot }}-1,5 \operatorname{tg} \alpha
\end{aligned}
$$

Where $h_{\max }$ is the maximum height allowed, $h_{\text {tot }}$ is the total height, $F d$ is the distance between the site and the building in front of it, Sd is the site length, and $\mathrm{Bd}$ is the distance between the site with the building behind it. FAR and ALO calculations use data of measurement results and standards applicable in Indonesia (Table 1). 
Table 1. Hotel site plan data

\begin{tabular}{cccccc}
\hline $\begin{array}{c}\text { Building Floor Coefficient } \\
\text { for Hotel }\end{array}$ & $\begin{array}{c}\text { Total } \\
\text { Siteplan } \\
\text { Area } \\
\text { (ha) }\end{array}$ & $\begin{array}{c}\text { Distance } \\
\text { from Front } \\
\text { Building }(\mathbf{m})\end{array}$ & $\begin{array}{c}\text { Site length } \\
(\mathbf{m})\end{array}$ & $\begin{array}{c}\text { Distance } \\
\text { from Back } \\
\text { Building (m) }\end{array}$ & $\begin{array}{c}\text { ALO }\left(^{\circ}\right) \\
\mathbf{\alpha}\end{array}$ \\
\hline 0.8 & 0.11 & 21 & 44 & 1 & 45 \\
\hline
\end{tabular}

The third model used the rules applicable to AYIA (Gita et al., 2014). The applicable regulation in Indonesia states that the maximum height is $45.5 \mathrm{~m}$ but the calculations should adjust the characteristics at each airport so that each airport should have its own altitude rules. This model considers aviation safety areas and regulation of altitude as in Equation (5);

$$
\mathrm{h}_{\max }=\mathrm{h}_{\text {stand }}-\Delta \mathrm{h}
$$

Where $h_{\max }$ is the maximum height allowed, $h_{\text {stand }}$ is the maximum standard for Ahmad Yani International Airport, and $\Delta \mathrm{h}$ is the height difference between the places measured based on the altitude of the airport. The calculations use secondary data from the airport authority and the measurement of the site's height (Table 2).

Table 2. Airport standard and Hotel future location data

\begin{tabular}{cccc}
\hline Airport $h_{\text {stand }}(\mathrm{m})$ & $\begin{array}{c}\text { Delta Height Ahmad Yani } \\
\text { Airport Location }(\Delta \mathrm{h}(\mathrm{m}))\end{array}$ & $\begin{array}{c}\text { Distance from airport to } \\
\text { location }(\mathrm{km})\end{array}$ & $\begin{array}{c}\text { Time to location } \\
(\text { Minutes })(\mathrm{v}=60 \mathrm{~km} / \mathrm{h})\end{array}$ \\
\hline 45.5 & 13 & 12.6 & 15 \\
\hline
\end{tabular}

\section{Results and Discussion}

\subsection{Building height, Aviation Safety, and Business Prospects}

The three methods produced different results. The FAR method produced a ratio of 1.25 . When compared with Shirvani's (1985) FAR model, the ratio explained that the maximum number of stories was six (Figure 2). In accordance with Handy et al. (2002), FAR was used to measure the density and intensity of human activities. If human activities can be optimized, the prospect of the hotel will grow better. Furthermore, the calculation with ALO noted the result of building height was $31.5 \mathrm{~m}$. With the each story is $4 \mathrm{~m}$, the maximum number of stories that can be made for the hotel is eight stories. The number of stories was identical to the number of rooms that can be maximized. In the point of view of hotels asbusiness prospects, the eight-story building is more profitable than six-story building.

In accordance with Ben-David et al. (2016) that the maximum number of rooms can optimize the hotel income. The third model was a model approach to aviation safety rules. In accordance with Wilke et al. (2015), the characteristics of the environment and the landscape of the airport determine the aviation safety. It means the design of the building height is very important. By conducting this method, the existence of the obstacles can be reduced. If the results of the two previous models were six and eight stories, then from this calculation model obtained from the maximum height of the airport area was $32.5 \mathrm{~m}$ or eight stories (four meters per story). This result is similar to the ALO model, hence, to maximize income and still pay attention to the aviation safety, the suggested number of stories is eight. 


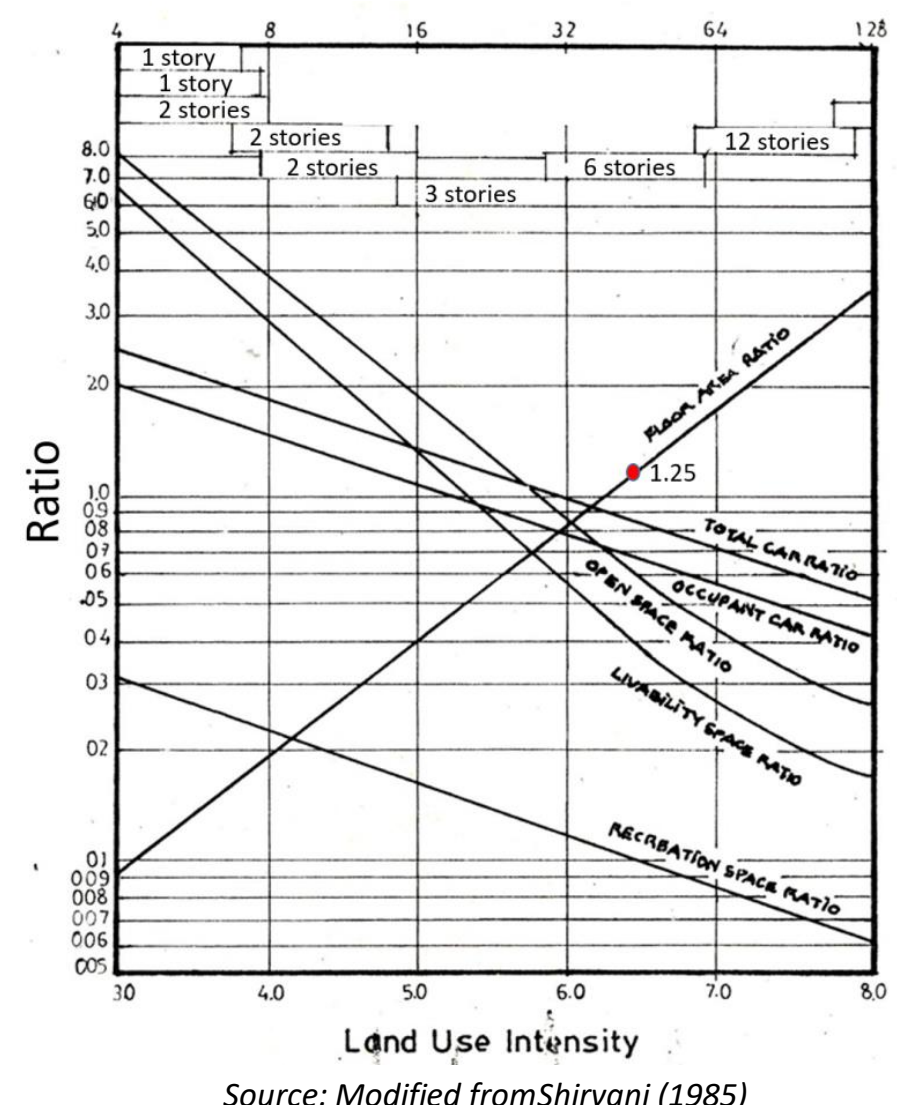

Figure 2. The Floor Area Ratio for Index 1.25

An eight-story hotel can have more facilities in its space function design. It is known that hotels have added their functions related to MICE so that some stories can be utilized for MICE activities. The function of this space is in line with Hsieh (2013) considering that the preparation of space for MICE is an important aspect in the variety of hotel services that can increase hotel revenues. Reviewed from their location, hotels have a strategic function if they are located in well-planned area. This statement is consistent with the research of Assaf et al. (2015) and Lado-Sestayo and Fernández-Castro (2018) that the strategic location is necessary to maximize the role of the hotel.

Based on the market value of the location, the position of Kaliwungu is strategic. First, It borders the city and northern coastal area of Semarang. The existence of this location is an opportunity to attract companies located in the North Coast of Semarang to conduct MICE activities. Second, the location is adjacent to Kendal Industrial Park located in Kaliwungu at only a distance of $0.75 \mathrm{~km}$ (Figure 3 ). Third, the location is adjacent to some tourist destinations such as Ngebum beach tour, Semarang Zoo, and Park by The Bay (Figure 4). These three advantages, related to the location, are thoroughly supported by the existence of the airport and the main transportation access. The strategic position, close to the industrial area and tourist destinations is the important point as it is in line with Shoval et al. (2011) that stating about integration of hotels and tourist destinations could bring positive impact for the hotel business. Furthermore, MICE opportunities are also considered as the hotels' business prospects, so with these opportunities, the variety of activities and revenue sources can be optimized. This fact is in line with Whitford's (2009) statement, who declared that MICE could helping the regional economic growth. 


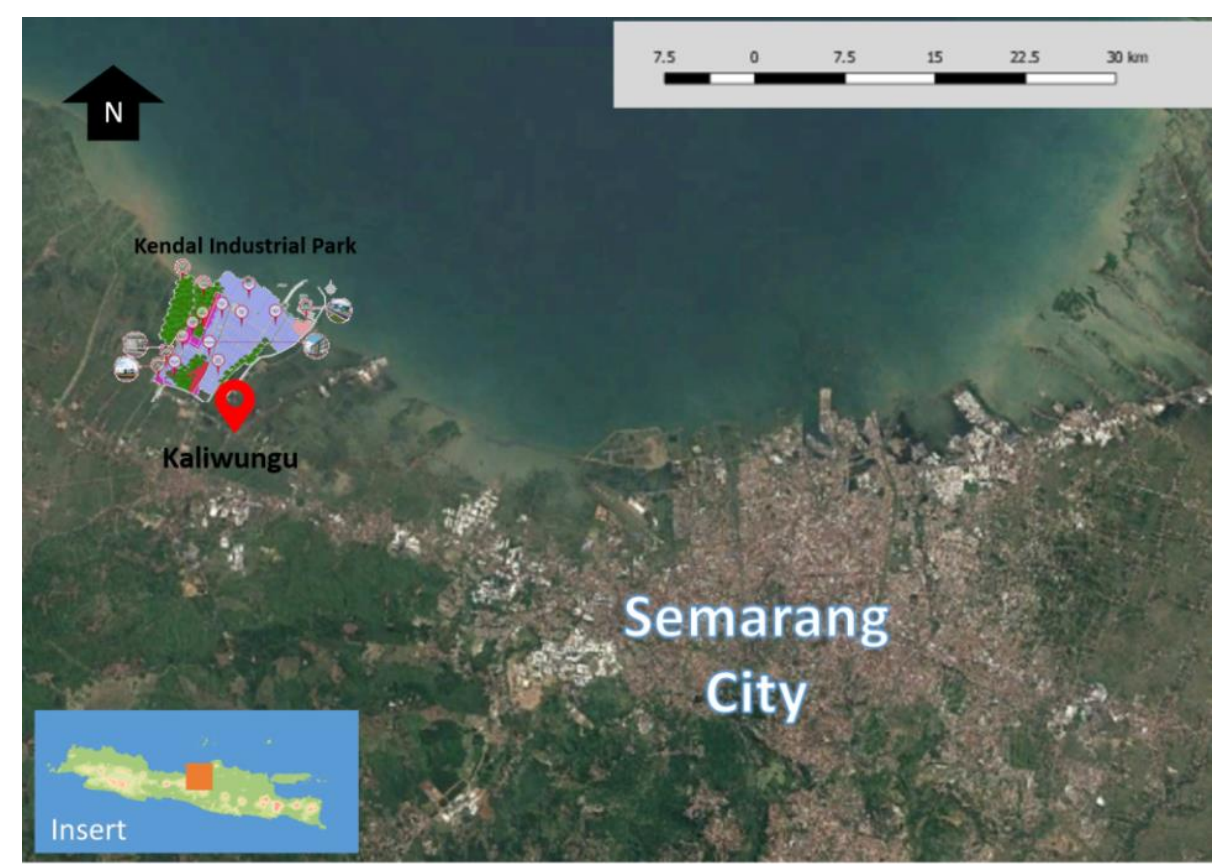

Source: Modified from Kendal Industrial Park, 2018

Figure 3. Hotels' Future Location and Kendal Industrial Park

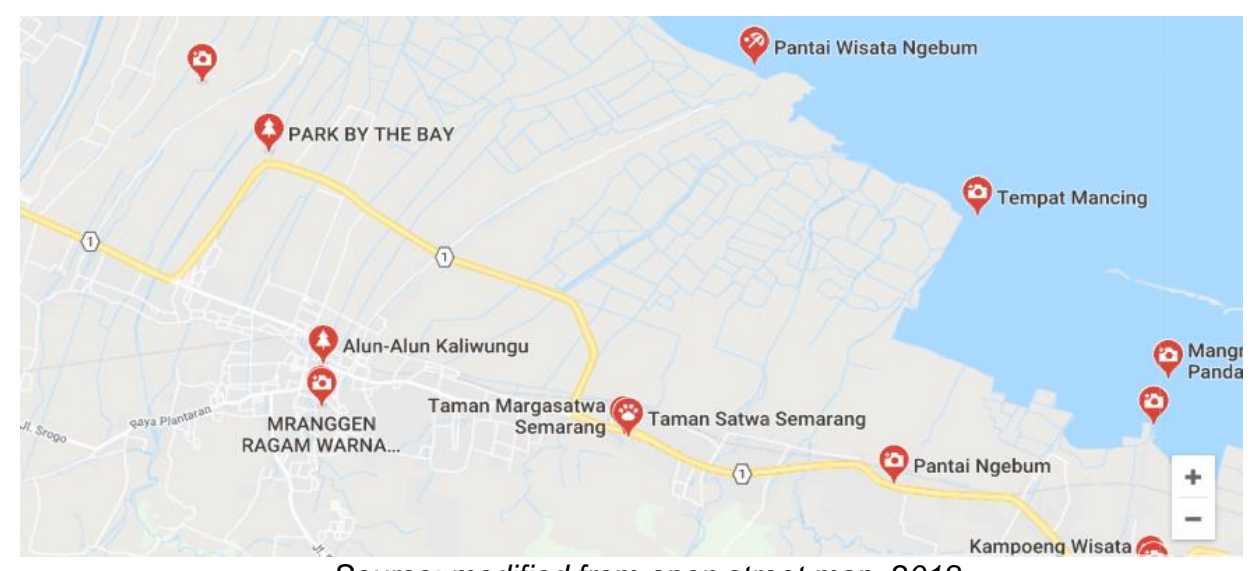

Source: modified from open street map, 2018

Figure 4. The Tourists Destination around the Hotels'Future Location in Kaliwungu

\subsection{Building regulation in aviation safety area}

Currently, the regulations available in the AYIA only regulate the aviation safety zones (Gita et al., 2014). It is necessary to make the building altitude regulation in each zone to assist in the aviation safety. These rules can safeguard the environment and landscape of airport from many obstacles. This idea is in line with Wilke et al.(2015) who emphasize that making the obstacle-free airport is mandatory. Furthermore, regulations of airports building'sheight should accommodate the spatial planning. With the previous results, the regulation stipulating 8-story building with $4 \mathrm{~m}$ in height for each story becomes the suggestion for future spatial planning especially in the urban areas of SMR located within the aviation safety zone.

The unavailability of regulations makes ambiguous information to local people particulary the matters related to building height within the airport area. Like Jawaid et al.(2018) who pointed out that the lack of regulation stipulating the details will create chaos. In addition, the environmental response to this lack of regulation makes the landscape development hindered. 
The synchronization between the buildings' height regulations and the spatial planning are also important because the spatial planning document in Kendal Regency has not accommodated the existence of aviation safety area of AYIA (Pemerintah Kabupaten Kendal, 2011). Moreover, the regulations are still partially and separately set between Kendal Regency and Semarang City. This is a risky situation considering that some areas of Kendal Regency (Kaliwungu District) are the peri-urban of Semarang City affected by urbanization in SMR areas. If the influence of urbanization is not immediately responded with good regulations, it can bring negative impact.

The impact of urbanization in SMR has been examined by several researchers (Buchori et al., 2018; Sejati \& Buchori, 2010). It is clear that the peri-urban unpreparedness in accepting urbanization has created problems; specificly, the absence of policy makers can trigger the uncontrolled peri-urban growth in SMR. In this case, the Regional Government of Kendal must conduct coorindation with the Muncipal Government of Semarang to tackle the problem about the peri-urban growth in Kaliwungu with collaborative planning. The coordination and the opportunities to integrated regulations for both regions should be prioritized. Officially, there should be synchronization of the spatial planning between Semarang city and Kendal Regency. Collaborative spatial planning is expected to bring solutions for the development of integrated regulations that is beneficial to both parties.

\section{Conclusion}

This study successfully answered the question of maximal height rules and the number of stories allowed for hotel buildings in peri-urban Semarang. Maximum height allowed is $32.5 \mathrm{~m}$ or 8 stories. According to the results, it necessary to create regulations regarding buildings height in Kaliwungu, Kendal, especially for the hotel buildings at AYIA aviation safety area in SMR. The existing regulations have not accomadated these issues, so collaborative planning should be carried out between the Municipal Government of Semarang City and the Regional Government of Kendal. With collaborative planning, problems in both regions related to the height of buildings such as hotels can be coordinated. The existence of these regulations is vital considering hotels are closely related to tourism support facilities that affect the regional income.

Further studies are needed to detail the appropriate regulation and appropriate collaborative model in managing the buildngs' height especially for hotels. With such advanced studies, appropriate collaborative spatial planning models can be realized. Indeed, the realization of this model is not easy, so the identification of stakeholders is very helpful in realizing the concept of collaborative planning to make spatial policies.

\section{Acknowledgments}

The authors would like to thank Dr. Yudi Basuki (the Head of Geometrics and Planning Laboratory) and Dr. Hadi Wahyono (the Head of Urban and Regional planning Department) for providing the research infrastructures. This research was financially supported by The Faculty of Engineering, Diponegoro University, Indonesia through the Excellent Research Grant 2018.

\section{References}

Adam, I., \& Amuquandoh, F. E. (2013). Dimensions of hotel location in the Kumasi Metropolis, Ghana. Tourism Management Perspectives, 8, 1-8. https://doi.org/10.1016/j.tmp.2013.05.003

Assaf, A. G., Josiassen, A., \& Agbola, F. W. (2015). Attracting international hotels: Locational factors that matter most. Tourism Management, 47, 329-340. 
https://doi.org/10.1016/j.tourman.2014.10.005

Ben-David, N., Teitler-Regev, S., \& Tillman, A. (2016). What is the optimal number of hotel rooms: Spain as a case study. Tourism Management, 57, 84-90. https://doi.org/10.1016/j.tourman.2016.05.016

Buchori, I., Sugiri, A., Mussadun, M., Wadley, D., Liu, Y., Pramitasari, A., \& Pamungkas, I. T. D. (2018). A predictive model to assess spatial planning in addressing hydrometeorological hazards: A case study of Semarang City, Indonesia. International Journal of Disaster Risk Reduction, 27(October 2017), 415-426. https://doi.org/10.1016/j.ijdrr.2017.11.003

Central Bureau of Statistics. (2017). Semarang in Figure 2017.

De Pelsmacker, P., van Tilburg, S., \& Holthof, C. (2018). Digital marketing strategies, online reviews and hotel performance. International Journal of Hospitality Management, 72(December 2017), 47-55. https://doi.org/10.1016/j.ijhm.2018.01.003

Ding, C. (2013). Building height restrictions, land development and economic costs. Land Use Policy, 30(1), 485-495. https://doi.org/10.1016/j.landusepol.2012.04.016

Doğan, B., Doğan, S., \& Yıldız, K. (2018). A new ex-ante efficiency criterion and implications for the probabilistic serial mechanism. Journal of Economic Theory, 175, 178-200. https://doi.org/10.1016/j.jet.2018.01.011

Gita, V., Subiyanto, S., \& Nugraha, A. L. (2014). Tinjauan Peta Kawasan Keselamatan Operasi Penerbangan (KKOP) Bandara Ahmad Yani Semarang. Jurnal Geodesi Undip, 3(1).

Handy, S. L., Boarnet, M. G., Ewing, R., \& Killingsworth, R. E. (2002). How the built environment affects physical activity: Views from urban planning. American Journal of Preventive Medicine, 23(2 SUPPL. 1), 64-73. https://doi.org/10.1016/S07493797(02)00475-0

Hermawan, A., \& Syahbana, J. (2015). Pemetaan Perkembangan Perhotelan di Pusat Perdagangan dan Jasa Kota Semarang dengan Sistem Informasi Geografis. Geoplanning: Journal of Geomatics and Planning, 2(1), 38-50.

Hsieh, P. F. (2013). Curriculum planning of MICE course in continuing education. Journal of Hospitality, Leisure, Sport and Tourism Education, 13(1), 107-122. https://doi.org/10.1016/j.jhlste.2013.08.002

Jawaid, M. F., Pipralia, S., \& Kumar, A. (2018). Review of environment responsiveness of building regulations in Jaipur. Journal of Urban Management, Article in(April). https://doi.org/10.1016/j.jum.2018.06.001

Lado-Sestayo, R., \& Fernández-Castro, Á. S. (2018). The impact of tourist destination on hotel efficiency: A data envelopment analysis approach. European Journal of Operational Research. https://doi.org/10.1016/j.ejor.2018.06.043

Madanoglu, M., \& Ozdemir, O. (2016). Is more better? The relationship between meeting space capacity and hotel operating performance. Tourism Management, 52, 74-81. https://doi.org/10.1016/j.tourman.2015.06.005

Pemerintah Kabupaten Kendal. (2011). Peraturan Daerah Kabupaten Kendal Nomor 20 Tahun 2011 Tentang Rencana Tata Ruang Wilayah Kabupaten Kendal 2011-2031.

Rogerson, J. M. (2013). Reconfiguring South Africa's hotel industry 1990-2010: Structure, segmentation, and spatial transformation. Applied Geography, 36, 59-68. https://doi.org/10.1016/j.apgeog.2012.06.004

Sejati, A. W., \& Buchori, I. (2010). A GIS Model for Predicting Disaster Prone Areas Affected by Global Sea-Level Rise: a Case Study of Semarang City. In ICRD Proceeding (pp. 512).

Sejati, A. W., Buchori, I., \& Rudiarto, I. (2018). The Impact of Urbanization to Forest Degradation in Metropolitan Semarang: A Preliminary Study. IOP Conference Series: Earth and Environmental Science, 123(1), 12011. Retrieved from http://stacks.iop.org/1755-1315/123/i=1/a=012011

Shirvani, H. (1985). The urban design process. Van Nostrand Reinhold Company.

Shoval, N., McKercher, B., Ng, E., \& Birenboim, A. (2011). Hotel location and tourist activity in cities. Annals of Tourism Research, 38(4), 1594-1612. 
https://doi.org/10.1016/j.annals.2011.02.007

van Sluisveld, M. A. E., Hof, A. F., van Vuuren, D. P., Boot, P., Criqui, P., Matthes, F. C., ... Watson, J. (2017). Low-carbon strategies towards 2050: Comparing ex-ante policy evaluation studies and national planning processes in Europe. Environmental Science and Policy, 78(April), 89-96. https://doi.org/10.1016/j.envsci.2017.08.022

van Wee, B. (2012). How suitable is CBA for the ex-ante evaluation of transport projects and policies? A discussion from the perspective of ethics. Transport Policy, 19(1), 1-7. https://doi.org/10.1016/j.tranpol.2011.07.001

Whitford, M. (2009). A framework for the development of event public policy: Facilitating regional development. Tourism Management, 30(5), 674-682. https://doi.org/10.1016/j.tourman.2008.10.018

Wilke, S., Majumdar, A., \& Ochieng, W. Y. (2015). The impact of airport characteristics on airport surface accidents and incidents. Journal of Safety Research, 53, 63-75. https://doi.org/10.1016/j.jsr.2015.03.006

Yang, Y., Luo, H., \& Law, R. (2014). Theoretical, empirical, and operational models in hotel location research. International Journal of Hospitality Management, 36, 209-220. https://doi.org/10.1016/j.ijhm.2013.09.004

Yang, Y., Wong, K. K. F., \& Wang, T. (2012). How do hotels choose their location? Evidence from hotels in Beijing. International Journal of Hospitality Management, 31(3), 675-685. https://doi.org/10.1016/j.ijhm.2011.09.003

Yang, Z., \& Cai, J. (2016). Do regional factors matter? Determinants of hotel industry performance in China. Tourism Management, 52(January 2014), 242-253. https://doi.org/10.1016/j.tourman.2015.06.024 